\title{
LEARNING MODEL TO IMPROVE TEENAGERS' SELF-ESTEEM AND MOTIVATION OF HAVING ACHIEVEMENT
}

\author{
Bambang Samsul Arifin \\ Universitas Islam Negeri (UIN) Sunan Gunung Djati Bandung \\ Jl. A. H. Nasution No. 105, Cibiru, Bandung, Jawa Barat, Indonesia 40614 \\ Email: bambangsamsularifin@uinsgd.ac.id
}

Received: 02, 2017. Accepted: 12, 2017. Published: 12, 2017.

\begin{abstract}
This article presents the process of developing an effective learning model to improve teenagers' selfesteem and motivation of having achievement. The research used mixed method research. In developing the learning model, the researcher carried out pre-study, development and model validation, and a model testing. The research generated a theoretically and empirically proper learning model to improve teenagers' self-esteem and motivation of having achievement at pesantren (Islamic boarding school). The learning model which was generated is MPPHM (Model Pembelajaran Peningkatan Harga Diri dan Motivasi /The Learning Model to Improve Self-Esteem and Motivation). This model was able to create the interesting, pleasant, and challenging study ambience to be followed by students. The results showed that it generated pedagogic development, provided the efforts to solve a problem in improving teenagers' self-esteem and motivation of having achievement, and served as the input for plan, implementation, and development of pesantren or other education institutions. This study was expected to benefit the teachers, principals and parents to pay attention to their children psychosocial factor that influence their children behaviors.
\end{abstract}

Keywords: Achievement, Learning Model, Motivation, Pesantren, Self-Esteem.

\begin{abstract}
ABSTRAK
Makalah ini memaparkan proses pengembangan model pembelajaran yang efektif untuk meningkatkan harga diri dan motivasi prestasi remaja. Metode penelitian yang digunakan adalah metoda campuran antara kualitatif dan kuantitatif. Dalam mengembangkan model pembelajaran, peneliti melakukan studi pendahuluan, pengembangan dan validasi model, serta pengujian model. Penelitian menghasilkan model pembelajaran yang layak secara teoritis dan empiris untuk meningkatkan harga diri dan motivasi prestasi remaja di pondok pesantren. Model pembelajaran yang dibasilkan bernama MPPHM (Model Pembelajaran Peningkatan Harga diri dan Motivasi). Model ini mampu menciptakan suasana belajar yang menarik, menyenangkan, dan menantang untuk diikuti oleh peserta didik. Hasil penelitian berimplikasi pada pengembangan pedagogi, memberikan solusi untuk memecabkan masalah peningkatan barga diri dan motivasi prestasi remaja, serta menjadi masukan bagi rencana, implementasi dan pengembangan institusi pesantren atau lembaga pendidikan lainnya. Temuan penelitian ini dibarapkan bermanfaat untuk guru, kepala sekolab dan orang tua agar lebih memperhatikan faktor psikososial yang mempengarubi perilaku remaja.
\end{abstract}

Kata Kunci: Prestasi, Model Pembelajaran, Motivasi, Pesantren, Harga Diri.

\section{INTRODUCTION}

World civilization today has changed very rapidly. Almost all life aspects are influenced by the very fast changes. One of the changing factor is technology of communication and information. The progress for technology of communication and information brings human life to global life characterized by competition both among individuals, groups, and among nations. A change in 
technology inevitably leads to a change in culture, a people's way of life (Murray, 2000; Mutekwe, 2012).

Positive responses in dealing with the development of life can be expressed by improving the quality of excellent human resources (Buller \& McEvoy, 2012; Huda, 2009; Jiang et al., 2012). Psychologically, if the human resources are not ready to face the changes, then the negative behaviors will emerge. The negative behaviors exhibited are self-low feelings, aggressive, criminal, and low motives of having achievement and low work ethos.

Therefore, Indonesian government tries to improve the human resources through education. One of the educational type institution in Indonesia is pesantren. Pesantren refers to Islamic educational institution. At pesantren, interaction between santri (students at pesantren) and and ustadz (teacher in pesantren) is strongly tied. The interaction is very helpful for santri in the process of learning and transfering Islamic values from the ustadz both directly and indirectly. The ages of santri are generally from 12 to 15 years old. According to theory of developmental psychology, the ages from 12 to 15 years old belong to adolescence. Adolescence is an important life segment in someone's development circle. It is also the time of transition which can direct to adult's healthy age development. Therefore, it is important to develop their potencies, talents, and interests. Teenagers should be given chances and freedom to organize themselves as a tool of maturity to become the pious, noble, patriotic, democratic, independent, and responsive generations towards other people's arguments (Agabrian, 2000; Konopka \& Beers, 2014).

However, in Indonesian context, condition of teenagers today is worrying. Many teenagers plunge into negative behaviors. In line with this, Yusuf (2000) mentioned some of bad behaviors including anarchist, free sex, prostitution, drug consumption, crimes and violence involvement.

Based on psychological views, the negative behaviors shown by teenagers contain two meanings. Firstly, it reflects low self-esteem. They prefer falling into the life trap which is considered modern to maintaining the local wisdom which features the high values in daily life. Secondly, it reflects teenagers' low achievement motivation. The low achievement motivation directs them prefer to like the life colored by deviant behavior better than developing potencies and achieving the achievement for their futures (Guerra, Williams, \& Sadek, 2011).

Morrison \& Cosden (1997) states that low self-esteem is closely associated with children bad behavior. Teenagers exhibit disrupting behavior in the classroom to gain attention because they performed poor in their academic achievement (Witzel \& Mercer, 2003). They substitute their failure in academic achievement by exhibiting bad behaviors (Broome, 1989). This calls for the effort on the part of the school to find way in order to tackle the issue of bad behavior and improve their self-esteem and gain in academic achievement (Bauman, 2012).

One of the efforts to solve children bad behavior is to improve their self-esteem. Selfesteem influences children behavior and motivation (Bauman, 2012; Lyons, 2012). Thus, to keep teenagers away from negative behaviors, this article presented a learning model which could improve teenagers' self-esteem and motivation of having achievement. The learning model was developed based on the results of observation at Pesantren at-Tarbiyah and Pesantren al-Aqsa. The learning model was expected to implicate pedagogic development, giving the solution to solve a problem in improving teenagers' self-esteem and motivation of having achievement, and becoming the input for plan, implementation, and development of pesantren institution.

\section{METHOD}

The research used mixed method research because it combined qualitative approach and quantitative approach. The former approach was related to development of learning model, while the latter approach was related to self-esteem, motivation of having achievement, and learning model testing. 
The steps taken by researcher in developing the learning model to improve teenagers' selfesteem and achievement motivation were: 1) conducting initial survey and the information collection; 2) planning and designing the model; 3) developing the early version of the model; 4) conducting early field test; 5) revising the main model; 6) testing main model; 7) revising operational model; 8) field testing operational model; 9) revising the model.

The steps were grouped on three main activities of the research, namely; (1) pre-study: referring to activities of pre-study which carried out to gain the beginning information from process of developing the learning model. All information acquired in the pre-study was used to design a theoretical-hypothetical model. Therefore, there were two steps taken by researcher in this pre-study. The steps included observation and the literature review. The latter refers to the concepts concerning the learning model, self-esteem, teenagers' motivation of having achievement, and educational system at pesantren. The results of literature review were used to determine a knowledge position about the learning model, teenagers' self-esteem and motivation of having achievement in applying the developed learning model; (2) model development and validation: There were three main activities in this stage namely; (a) content development by experts; (b) empirical validation by practitioners; and (c) hypothetical model revision for operational model formulation. The techniques used by experts in content validation was assessment to make decision. This was done by sending model scripts, guides, and validation sheets to validators. The questions in validation sheets encompassed contents, structures, and evaluations. Consequently, these results of validation sheets were made inputs in revision and development of model. Empirical validation from practitioners was committed to obtain the inputs from the practitioners in implementation of learning model. Having accomplished these stages, the research gained information regarding the advisability in using the effective learning model to improve teenagers' self-esteem and achievement motivation developed at pesantren. Results of empirical validation were made inputs to revise and develop the model; (3) model testing: On this stage, the operational model which had been formulated on the stages of validation and development was then empirically tested to find out the effectiveness of model. The technique used in model testing was quasi-experiment design. The scheme of quasiexperiment design in model testing can be seen in Figure 1.

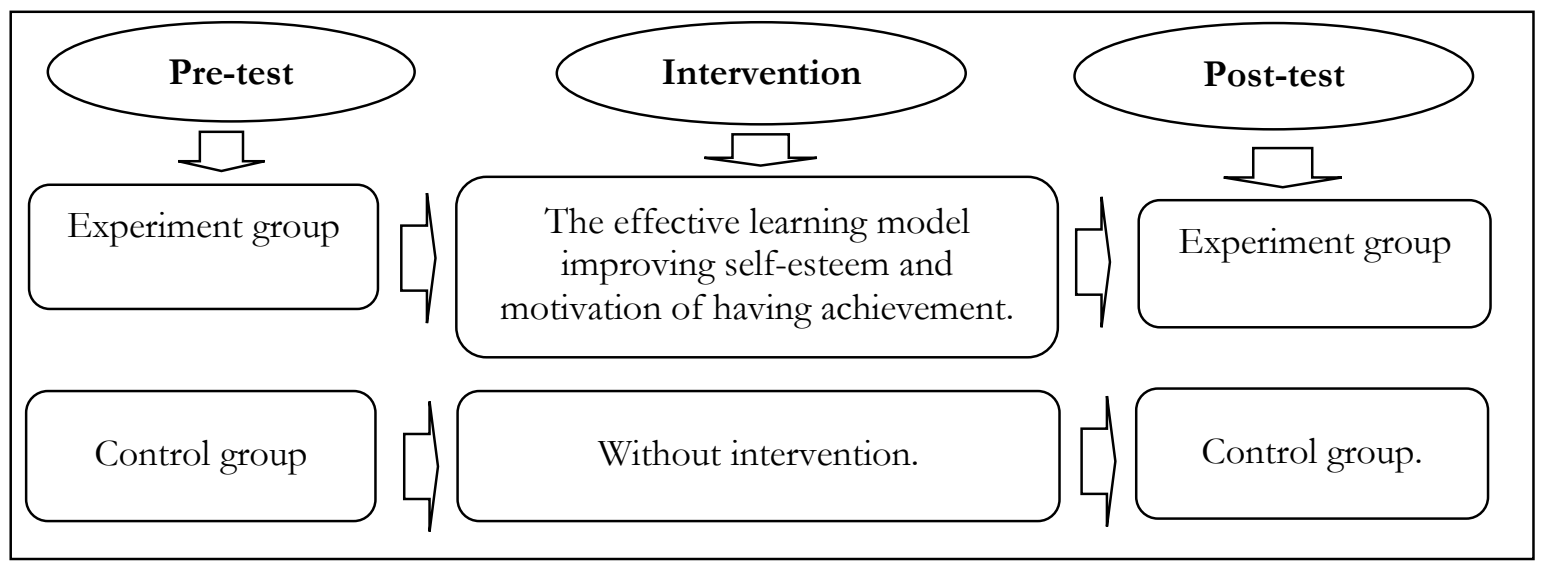

Figure 1. The Scheme of Quasi-Experiment Design in Trial of Model. 


\section{RESULTS AND DISCUSSION}

\section{Pre- Study and Literature Review}

Process of the learning design was started by a pre-study in the form of the initial observation and the literature review to determine a position of model implementation area. In the stage of initial observation and the literature review, this study expected to generate a hypothetical model. Hypothetical model was supported by a strong theoretical frame and a grounded implementation opportunity for the learning at pesantren. Such process is emphasized by Borg and Gall (1983) that the literature review is conducted to collect information in planning and developing the model. One of the goals was to determine the review area or the model implementation.

Besides the literature review, the field study or initial observation was carried out in obtaining information and data in designing a learning model. Initial observation was conducted to capture general description concerning self-esteem, teenagers' motivation of having achievement, and the learning process at pesantren. Initial observation also digged data and information concerning the components related to the learning process and the environment of pesantren. Results of field study and literature review are presented as follows:

\section{Profile of Pesantren at-Tarbiyah and Pesantren al-Aqsha}

Pesantren at-Tarbiyah is geographically located in a very strategic location; that is, in Cimalaka Subdistrict, Sumedang Regency West Java. This pesantren established since $5^{\text {th }}$ March 1989 and has gone through a rapid development. The number of alumni up to 2015 has reached 786 people spreading in districts in Indonesia, especially in West Java. This pesantren is one of the pesantrens in West Java which can be defined as pesantren salafi.

In carrying out duties to enforce Islamic education, this pesantren follows the clear vision and missions. The vision and mission of the pesantren's are set in its educational goals. General objectives of the Pesantren at-Tarbiyah include guiding santri to be human beings having Islamic personality and are able to be mubaligh (preacher) in society through sciences and charity. These objectives are broken down in pesantren's specific goals.

The curriculum which is developed at Pesantren at-Tarbiyah is based on classical holy books and modern ones. It makes and determines the curriculum by itself without following the educational standards determined by government. Environment of pesantren is an integrated part in pesantren's curriculum which is designed to support the process of achieving the learning goals. Santri at Pesantren at-arbiyah follow formal education beyond the pesantren. The condition at pesantren is already relevant to necessities of enforcing the learning. The findings related to the learning enforcement at Pesantren at-Tarbiyah are colored by study cultures at public pesantren.

Facilities and infrastructure of the learning become important in the learning process to reach the appointed goals. The finding results show that pesantren had the adequate facilities and infrastructure of learning; however, it was not maximal yet in its management. According to santri, the circumstance at pesantren was conducive enough for continuity of learning process.

Meanwhile, Pesantren al-Aqsa was established on 2nd February 1994 located in Jatinangor Subdistrict, Sumedang Regency West Java. The goal of Pesantren al-Aqsa is to form generation of Muslims with good quality both in religious sciences and in general sciences.

Educational implementation at Pesantren al-Aqsa is based on vision and missions showing clear future orientation. Vision of Pesantren al-Aqsa entails the first modern pesantren which is excellent at aspects of science and theology in level of Province West Java in 2014, while the missions that it executes consisting of nine points as the clarification of the missions. These missions have been operationally clarified into form of pesantren's goals. These are the goals which become a success standard for implementing the education of pesantren.

The curriculums which are developed at Pesantren al-Aqsa are the curriculum of pesantren and general curriculum which is the same as the curriculum from government. Curriculum of 
pesantren refers to the curriculum developed by Pesantren Modern Gontor and curriculum of pesantren salafi. These two curriculums are integrated to be a new curriculum developed at Pesantren alAqsa. This curriculum contains subjects or recitation of Imlä', Tafsir, Hadits, Mahfüūāät, Nahwu, Sharaf, Muthälaah, Insyä, Conversation, English Contextual, Ta'lim Muta'alim, and al-Akblak Li alBanin. In addition, there are curriculums of local content in the form of non-academic extracurricular activities, such as intellectual activities, sports, and cultural arts.

The learning process at Pesantren al-Aqsa starts from the moment santri wake up to the moment before they go to sleep. The activities at the pesantren begin from the santri wake up by doing the morning activities in the mosque until seven o'clock. From seven o'clock in the morning to afternoon, santri follow the formal education at a school which is managed by the pesantren. The activities of pesantren are continued after ashar prayer until 19:30. From 19:30 to 21:00 the santri study under supervisor's supervision. After studying, it is followed by activities of spiritual lessons and the advice which are preached by supervisors until 21:30. Santri get the advice about ethics and pray together. Then it is followed by recitation of Qur'an which is recited to entire neighborhoods of pesantren until they go to bed.

Facilities and infrastructures which Pesantren al-Aqsa provides are already adequate and supportive towards the learning process. $83 \%$ of the santri said that facilities and infrastructures at Pesantren al-Aqsa are adequate and conducive both about study room, media and the learning tools, worship facilities, and about neighborhood of pesantren.

\section{The Learning Model Used at Pesantren at-Tarbiyah and Pesantren al-Aqsha}

The learning model at Pesantren at-Tarbiyah is based on practical experiences from ustad\%: Thereby, the learning process at Pesantren at-Tabiyah shows more about roles of ustadz in conditioning the learning activities. Ustadz analyze curriculum and santri's needs, prepare the resources, coordinating the related parties and innovate to perfect the learning process. The learning process takes place in the mosque or around pesantren.

Process of formal learning at Pesantren al-Aqsa takes place in the classroom, while process of pesantren learning covers reviewing yellow holy book and other holy books carried out by balaqah or gathering in the mosque or around pesantren. The learning model applied at Pesantren al-Aqsa is various. Ustadz, and ustadzah in Pesantren innovate in their teaching and learning process.

\section{Teenagers' Self-Esteem at Pesantren at-Tarbiyah and Pesantren al-Aqsa}

In relation to teenagers' self-esteem, the researcher conducted initial observation at Pesantren at-Tarbiyah and Pesantren al-Aqsa. Initial observation was conducted on 25 students at Pesantren at-Tarbiyah and Pesantren al-Aqsa. Its results show that $76 \%$ of students had moderate self-esteem, and $24 \%$ of the others were high. While the results of observation at Pesantren alAqsa show that $88 \%$ of students had high self-confidence, and $12 \%$ of them were moderate.

Based on the observation data, the average of teenagers' self-esteem at Pesantren at-Tarbiyah was on adequate category, while the average of teenagers' self-esteem at Pesantren al-Aqsa was on high category. This circumstance points out a real difference in teenagers' self-esteem at both pesantren.

\section{Circumstance of 'Teenagers' Motivation of Having Achievement at Pesantren at- Tarbiyah and Pesantren al-Aqsha}

Results of initial observation at pesantren at-Tarbiyah related to motivation of having achievement show $84 \%$ of teenagers point out moderate, and $16 \%$ of them demonstrate high category. Meanwhile, observation at Pesantren al-Aqsa shows $80 \%$ of teenagers have high motivation of having achievement, and $20 \%$ of them are moderate.

Teenagers' motivation of having achievement in these results of research describes a different circumstance. The difference seems from results of data analysis showing that data of 
teenagers' motivation of having achievement at Pesantren at-Tarbiyah are averagely on moderate category, while teenagers' motivation of having achievement at Pesantren al-Aqsa is averagely on high category. This circumstance points out the real distinction in teenagers' motivation of having achievement at both pesantren.

\section{Literature Review of the Self-Esteem and Achievement Motivation}

Every teenager has persistence to gain the competitive and excellent abilities and capabilities which are beneficial for social and national life (DuBois \& Hirsch, 2000). In line with this view, Yusuf (2000) describes that teenagers' periods are the important life segments in someone's development circle and are the transition periods which can be directed to healthy maturity development.

Meanwhile, the challenges inhibiting in society's life reality keep on booming. Such circumstance is generally formed by two dominant factors in life distance. The two dominant factors are internal factor and external factor. The former is the factor which is in teenagers. The latter refers to what is frequently called the term of neighborhood is everything which is outside individuals both social neighborhood and non-social or material neighborhood.

Self-esteem and motivation of having achievement are parts which cannot be separated from development tasks experienced by teenagers as individuals (Mullai, Macaj, \& Kotherja, 2017; Sadovnikova, 2016). It is because these two aspects have roles in developing teenagers' personality, especially regarding their identity development. Teenagers' formation of personality can work out well if they have the high self-esteem and motivation of having achievement. On the contrary, teenagers having the low self-esteem and motivation of having achievement will encounter obstacles in their personality development (Gecas, 1982; Schwartz, Lowe, \& Rhodes, 2012).

Teenagers' self-esteem and motivation of having achievement have a very important meaning for their development. In teens, individuals go through the process of very rapid changes both physically and psychologically in the forms of attitude and behavior. On physical aspect, the changes on each stage of development lead to maturity. Physical maturity will bring about individuals' readiness to do their functions in accordance with level of maturity and stage of development.

In general, Hurlock (1959) has stated that the changes of attitude and behavior which happen to teenagers cover four types. These four kinds of change are: (1) the higher emotion (2) the changes on interests and roles, (3) the shift of values, and (4) ambivalent behavior towards the entire changes occurring. These four kinds of change of attitude and behavior work out according to process of development experienced by teenagers.

All the changes experienced by teenagers can elicit hesitation concerning them, including self-confidence and motivation of having achievement. Nevertheless, this can be overcome if teenagers have knowledge about them and identify themselves so that they acquire the convincing roles. Then, the intellectual, social, and emotional developments are a result of the changes happening physically (Lerner \& Hultsch, 1983, p. 105). Thereby, it can be said that the changes on physical aspect experienced by teenagers have influences towards their psychological changes.

In development of self-identity, self-esteem is a very important aspect for teenagers. Teenagers having high self-esteem will get ease in undergoing their development of self-identity optimally. Therefore, in teens, somebody has begun thinking about "who is he and what abilities does he have". It means that in teens they will think about identity and abilities which they possess. Thereby, self-esteem holds important roles for formation of teenagers' self-identity (Papalia, Olds, \& Feldman, 1998, p. 373; Tsang, Hui, \& Law, 2012).

Development of teenagers' self-esteem and motivation of having achievement is affected by internal factor emerging from inside individuals and external factor emerging from outside 
individuals. The learning process is one of the external factors which are considered helpful in development of teenagers' self-esteem and motivation of having achievement. Therefore, the learning followed by teenagers needs a helpful model in improving their self-esteem and motivation of having achievement.

Model is a mini three-dimension construction which is expected to be able to describe, explain, and find a design presenting from the actual form (Hattie \& Donoghue, 2016). Learning model which was developed on this research was the learning model to improve teenagers' selfesteem and motivation of having achievement at pesantren.

Learning model which was developed on this research is in line with the model which is put forward by Wolfe about the behavior models (Joyce, Weil, \& Calhoun, 2000; Vihman, 2017). The behavior learning models emphasizes a creation of study environment to manipulate the behavior reinforcement so as to form patterns of the expected behaviors (Indrawati, 2011). A characteristic of behavior models is the existence of tendency to resolve the study assignments to a number of consecutive small behaviors. The learning activities are broken down into concrete steps and can be observed by teachers and students (Joyce et al., 2000, p. 6).

The above theoretical and empirical reviews encourage necessities of developing the learning models to improve teenagers' self-esteem and motivation of having achievement at pesantren. This learning model has important roles in arousing and raising self-esteem and motivation of having achievement.

Process of learning followed by santri is a precious experience for formation of behavior changes in accordance with the learning goals which have been fixed on by ustad\%. The appointed learning objectives have additional values which can be picked by santri for development of potency which they have, particularly about self-esteem and motivation of having achievement. It means, in addition to being able to achieve the learning goals, it can also improve santris self-esteem and motivation of having achievement.

The founding which is built by pesantren is a system which consists of roles from four elements involved around pesantren. The four elements can be seen in Figure 2.

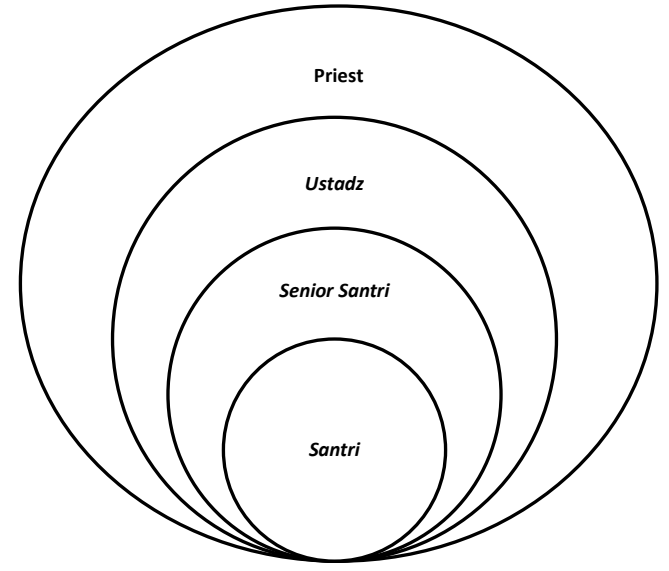

Figure 2. Elements of Practitioners for the Founding of Pesantren.

\section{Development and Model Validation}

The above empirical and theoretical reviews encourage necessities of developing the learning models to improve teenagers' self-esteem and motivation of having achievement at pesantren. The learning models developed refer to success achieved at Pesantren al-Aqsa. As presented in observation results, teenagers' self-esteem and motivation of having achievement at Pesantren al-Aqsa averagely have high category. Pesantren al-Aqsa is one of the institution of modern Islamic education implementing education of pesantren as well as education in level of junior high school. Process of education enforced by this pesantren is influenced by values of 
Islamic teachings, particularly the learnings of faith, noble morals (al-akbläk al-karimab), selfesteem, and motivation of having achievement carried out regularly and continually.

In general, educational process at pesantren is an implementation from the objectives of national education as regulated in the Laws of National Education System No. 20 year 2003. Clarification of the goals is formulated in the form of pesantren's educational objectives having the focus of review and learning on Islam. Islamic values are shown in daily life patterns in pesantren's educational system.

The researcher reviewed deeply main elements of the learning model taking place at Pesantren al-Aqsa in improving santri's self-esteem and motivation of having achievement. So, the learning model was expected to emerge to improve teenagers' self-esteem and motivation of having achievement which can be used at other pesantren.

From the review results which have been done, the learning model developed is named MPPHM (Model Pembelajaran Peningkatan Harga diri dan Motivasi / The Learning Model to Improve Self-Esteem and Motivation). MPPHM refers to the learning process carried out by ustadz at Pesantren al-Aqsa. MPPHM focused on factuality of lesson materials and application of santri's comprehension towards the learned materials. The steps of learning on MPPHM were as follows.

1. Formulating the learning goals which will be achieved. The goals were clearly formulated as a direction which would be achieved in process of learning.

2. Formulating the activities which would be carried out in programs of learning, both on activities of material factuality and on application of comprehension.

3. Formulating the process taken in the learning, covering: muqadimah (introduction or the beginning activity of the learning), the learning activities by presenting the material factuality conveyed, and application of comprehension towards the learned materials.

4. Evaluating learning. On evaluation activity, the assessment was committed towards process and study results. The assessment was carried out to find out accomplishment of the appointed learning objectives. In this research, assessment also encompassed the assessment of self-esteem and motivation of having achievement.

Hypothetical model which had been formulated was then translated into form of lesson plans. The lesson plans were validated to obtain advisability of contents and practical advisability. Results of content validation show that all aspects and structures which build hypothetical model have adequate advisability. Even so, validators gave advice and inputs to revise the developed model. The revision which was advised was on clarity aspect of the learning goal formulation related to the available time allocation.

Based on the inputs from validators, the researcher revised formulation of learning model. The learning model developed should be definitely able to improve teenagers' self-esteem and motivation of having achievement at pesantren. The learning model should also be able to arouse enthusiasm, pleasure, and happiness of ustadz carrying it out and santri following it. It is because basically everybody does not like monotonous circumstances, let alone students in teens. Santri will be pleased to learn something when they understand and can follow plot of a material which is being learned. However, they will feel bored, confused, and confined when they cannot understand the material which is being discussed or their lesson material is not challenging enough (Furqan, 2006).

Then, the learning model developed to improve teenagers' self-esteem and motivation of having achievement at pesantren was viewed important to conduct a trial. MPPHM's data of implementation results were outlined on the following sections. 


\section{Implementation of Learning Model for Improving 'Teenagers' Self-Esteem and Motivation}

Analysis results of the MPPHM's implementation pointed out teenagers' self-esteem and motivation of having achievement after following the learning model on high category. The height of teenagers' self-esteem and motivation of having achievement seems from the average of MPPHM's trial results in experiment group compared to control group as seen in Table 1 and Table 2. Furthermore, the average of self-esteem of experiment and control group was compared using paired t-test as seen in Table 2 and Table 4.

Table 1. Average of Self-Esteem of MPPHM's Trial Results.

\begin{tabular}{ccc}
\hline Trials: & \multicolumn{2}{c}{ Average } \\
\cline { 2 - 3 } & Experiment Group & Control Group \\
\hline First & 80.48 & 74.72 \\
\hline Second & 80.69 & 74.73 \\
\hline Third & 84.61 & 77.56 \\
\hline
\end{tabular}

Table 2. Paired Samples Test for Self-Esteem of MPPHM's Trial Results.

\begin{tabular}{|c|c|c|c|c|c|c|c|c|c|}
\hline & \multicolumn{5}{|c|}{ Paired Differences } & \multirow[b]{3}{*}{$\mathrm{T}$} & \multirow[b]{3}{*}{$\mathrm{df}$} & \multirow{3}{*}{$\begin{array}{l}\text { Sig. (2- } \\
\text { tailed) }\end{array}$} \\
\hline & & \multirow[b]{2}{*}{ Mean } & \multirow{2}{*}{$\begin{array}{c}\text { Std. } \\
\text { Deviation }\end{array}$} & \multirow{2}{*}{$\begin{array}{l}\text { Std. } \\
\text { Error } \\
\text { Mean }\end{array}$} & \multicolumn{2}{|c|}{$\begin{array}{l}95 \% \text { Confidence } \\
\text { Interval of the } \\
\text { Difference }\end{array}$} & & & \\
\hline & & & & & Lower & Upper & & & \\
\hline $\begin{array}{l}\text { Pair } \\
1\end{array}$ & $\begin{array}{l}\text { Experiment } \\
\text { - Control }\end{array}$ & 6.25667 & .69429 & .40085 & 4.53196 & 7.98137 & 15.609 & 2 & .004 \\
\hline
\end{tabular}

Table 3. Average of Motivation of Having Achievement of MPPHM's Trial Results.

\begin{tabular}{ccc}
\hline Trials & \multicolumn{2}{c}{ Average } \\
\cline { 2 - 3 } & Experiment Group & Control Group \\
\hline First & 135.83 & 120.31 \\
\hline Second & 138.69 & 120.40 \\
\hline Third & 142.24 & 121.09 \\
\hline
\end{tabular}

Table 4. Paired Samples Test for Motivation of Having Achievement of MPPHM's Trial Results.

\begin{tabular}{|c|c|c|c|c|c|c|c|c|c|}
\hline & & \multicolumn{5}{|c|}{ Paired Differences } & \multirow[b]{3}{*}{$\mathrm{t}$} & \multirow[b]{3}{*}{$\mathrm{df}$} & \multirow{3}{*}{$\begin{array}{l}\text { Sig. } \\
(2- \\
\text { tailed) }\end{array}$} \\
\hline & & \multirow[b]{2}{*}{ Mean } & \multirow{2}{*}{$\begin{array}{c}\text { Std. } \\
\text { Deviation }\end{array}$} & \multirow{2}{*}{$\begin{array}{l}\text { Std. } \\
\text { Error } \\
\text { Mean }\end{array}$} & \multicolumn{2}{|c|}{$\begin{array}{c}95 \% \text { Confidence } \\
\text { Interval of the } \\
\text { Difference }\end{array}$} & & & \\
\hline & & & & & Lower & Upper & & & \\
\hline Pair 1 & $\begin{array}{l}\text { Experiment } \\
\text { - Control }\end{array}$ & 18.04333 & 3.23706 & 1.86892 & 10.00204 & 26.08463 & 9.654 & 2 & .011 \\
\hline
\end{tabular}


Data in Table 1 and Table 3 show that empirically MPPHM can arouse teenagers' selfesteem and motivation of having achievement. Self-esteem and motivation of having achievement show up due to manipulation of situation which is created in form of active learning. Santri were encouraged to actively study by reviewing factuality of lesson materials. Factuality is conducted by relating events or incidents occurring around santri to the learned materials and the application of material comprehension.

These results of empirical findings are in line with conceptual views about the development of self-esteem and motivation of having achievement through learning process. Elements of MPPHM are oriented on the development of teenagers' self-esteem and motivation of having achievement. Santris ability in controlling behavior, the care which was accepted from other people, efforts to follow standards of moral and ethics, and the ability to achieve their achievement go up after following the learning process with MMPHM. The increase also happened to aspects of value, aspiration, and ability to survive the santri's self.

There are a few conditions which can affect somebody's self-esteem. The first one is peers. They influence somebody's personality through two ways, those are: (1) self-concept is a reflection about social neighborhood towards self, (2) sometimes somebody decides to be in pressure to develop characteristic of personality so as to be recognized by social neighborhood or group. The second one is aspiration. If somebody has unrealistic wishes, he will be susceptible to failure. In such condition, it will bring about unable circumstance and reaction of surviving where the person will tend to defeat other people over his failure.

Based on the view above, it can be understood that one of the factors which can affect formation of somebody's self-esteem is the social neighborhood in which someone lives. Social neighborhood can influence formation of self-esteem. Individuals begin to realize that they feel honorable as individuals with their neighborhood. Experience, success, friendship, and fame can increase self-esteem. It all can occur at pesantren as a centre of social interaction process. Therefore, the pesantren enforcing the education through learning process has important roles in developing santri's self-esteem as students. One of the teenagers' social interaction places is when following the learning process performed by pesantren. Likewise, the improvement happens to dimensions of teenagers' motivation of having achievement encompassing six dimensions. The six dimensions of motivation of having achievement are: (1) insisting to achieve the study achievement, (2) looking for feedbacks over their study achievement, (2) performing better and creative activities to reach the achievement, (4) carrying out the study tasks diligently and persistently, (5) feeling unafraid of failure and daring to take the risks in performing the study activities, and (6) relying on the planned-anticipation to success of study assignments.

Theoretically, the learning is a two-way interaction from an ustadz or a teacher and students playing an intense communication and directed to an appointed goal. At pesantren, the interaction occurs between priest, ustadz and santri in the learning process or other pesantren activities. In line with this, Trianto (2010) states that the learning can be defined as an aware effort from a teacher to thoroughly teach students (directing students' interaction to other study sources) in achieving the expected objectives.

Effectiveness of a learning model used at pesantren is highly determined by the abilities of ustadz and santri. Ustadz should be skillful in formulating the plans and enforcing the learning; while santri should be thorough and quick in accepting the learning materials. Even so, the effectiveness of a learning model is marked by indicator of model effectiveness in the learning as Trianto puts forward; those are, percentage of students' high study time is devoted on activities of teaching and learning, (2) average of behavior carries out high tasks, (3) decision between learning material contents and students' ability (orientation of study success) is featured, and (4) developing the close and positive study ambience, developing structure of class 
supporting point two; that is, average carries out high tasks without neglecting point four; that is, good study ambience (Trianto, 2010).

Self-esteem is an assessment conducted by individuals concerning how far the individuals believe themselves as the able, meaningful, successful, and valuable people. It means that selfesteem is a personal decision concerning self-preciousness expressed in attitudes becoming somebody's grip towards themselves. The belief encourages individuals to express it in attitude and behavior with full of self-confidence.

Meanwhile, motivation of having achievement in this research is an encouragement in individuals to well improve their quality of performance or better than previous achievement effectively and efficiently. In keeping with the clarification, McClelland puts forward seven kinds of somebody's behavior characteristics which have motivation of having achievement. The seven behavior characteristics are shown by individuals in the following forms: a) a wish of having achievement well; b) a planned-anticipation; c) doing activities and creations to achieve aspiration; d) strong feelings to achieve the aspiration; e) unafraid of failure and daring to take the risks; f) having personal responsibility, and g) having standard of internal and external excellences (McClelland, 1953).

Based on process and results of MPPHM development, this learning model gives theoretical and empirical belief to be implemented at pesantren in trying to improve teenagers' self-esteem and motivation of having achievement. Therefore, in the following discussion the researcher presents the excellences, weaknesses, and opportunities of MPPHM implementation.

\section{Excellences of MPPHM}

Good learning is marked by the learning goal accomplishment effectively and efficiently in pleasant ambience. The learning generates the students with high self-esteem and motivation and it is expected to be able to encourage them to optimally achieve the academic success. Therefore, it needs a precise learning model to meet the hope. One of the models which are in accordance with this hope is MPPHM which has some excellences.

MPPHM is a new learning model utilizing a learning process as facilities of intervention towards teenagers' self-esteem and motivation of having achievement. MPPHM gives pleasant and challenging study experiences for ustadz and santri, so that empirically it can improve the understanding, comprehension, skills, and certain behavior which will be developed, especially regarding teenagers' self-esteem and motivation of having achievement at pesantren.

To some extent, learning model at several pesantren goes monotonous, boring, and lacks direct experiences from application of lesson materials conveyed. MPPHM gives the precise solution towards such learning process.

\section{Weaknesses of MPPHM}

There are some weaknesses of MPPHM presented as follows. MPPHM is effective to be used to improve teenagers' self-esteem and motivation of having achievement with requirement of openness. All stakeholders of pesantren practitioner component should be open towards development sciences in implementing this model. If this requirement is met, then process of enforcing the learning model can take place maximally and can give optimal effects in reaching the learning objectives. On the contrary, if the stakeholders of pesantren behave closed, then this application of learning model will encounter hindrances.

The effectiveness of MPPHM is newly tested in improving self-esteem and motivation of having achievement. Therefore, this learning model has not given belief to develop santris potencies beyond aspects of self-esteem and motivation of having achievement; whereas, a learning model is expected to be able to be used to develop students' variety of potencies. The learning should be able to make students burgeon maximally in accordance with their tasks and 
stages of development so as to be the quality generation. It is this circumstance which becomes the weaknesses of MPPHM.

\section{Opportunities of MPPHM Implementation}

In general, teenagers following education at pesantren go through process of development which is the same as the ones who follow the education at public schools. In teenager phase, they experience rapid changes both physically and psychologically, including self-esteem and motivation of having achievement. Teenagers going through high development of self-esteem and motivation of having achievement will gain easiness in achieving a goal and their process of development. Hence, the learning which gives opportunities of developing teenagers' potencies is viewed to have very important roles in forming changes of attitude and behavior, including self-esteem and motivation of having achievement.

However, the learning model which can improve self-esteem and motivation of having achievement is still very rare. So, MPPHM is expected to be an alternative learning model used at pesantren to increase santri's self-esteem and motivation of having achievement. This is the one which becomes opportunities of enforcing the learning model for improving teenagers' selfesteem and motivation of having achievement at pesantren.

\section{CONCLUSION}

The learning enforcement at modern pesantren generally tends to try in improving self-esteem and motivation of having achievement. The methods of learning used by ustadz are various. However, the learning method which is used features more on santri's active roles during the learning. One of the learning models found in this research is the learning which provides factuality and application of lesson materials understood by santri. Factuality is conducted by relating events or phenomena happening around santri. By way of the steps, this learning model has been theoretically and empirically able to arouse teenagers' self-esteem and motivation of having achievement at pesantren. This model is then named MPPHM. It is found that MPPHM complied with educational pattern conducted in Al-Aqsa pesantren. MPPHM encouraged students to boost efforts to improve self-esteem and achievement motivation of adolescents. It can be adapted and used in pesantren or other educational institutions, because it has been proven empirically and theoretically that it has an effect on improving self-esteem and achievement motivation of adolescents. Applying MPPHM overcomes the issues related to self-esteem and achievement motivation of adolescents among students in the school. Learning model discussed in this study can be a source of research for universities that provide Islamic Education and Psychology courses. The departments can consider MPPHM by designing and developing the materials and strategies delivered to their students. Learning materials and strategies can be directed to provide additional competencies for students to be able to understand and apply MPPHM for self-esteem improvement and achievement motivation of adolescents. On the other hand, the weakness of MPPHM implementation in learning concerns a long time due to comprehensive research procedures. It is recommended for other researchers to conduct study on the development of MPPHM to examine the effectiveness of this model on more diverse changes and targets. In the literature review the aspects of self-esteem that include sustainability, values, aspirations, and self-defense can be improved through the application of the learning process as part of behavioral changes gained from experience in learning.

\section{BIBLIOGRAPHY}

Agabrian, M. (2000). Relationships between school and family. Forum: Qualitative Social Research, $8(1)$, 1-34. Retrieved from http://www.qualitative-research.net/index.php/fqs/ article/view/209/461 
Bauman, S. (2012). The importance of self-esteem in learning and behavior in children with exceptionalities and the role magic tricks may play in improving self-esteem and in motivating learnin. University of Central Florida. Retrieved from http://stars.library.ucf.edu/cgi/ viewcontent.cgi?article $=2343 \&$ context $=$ honorstheses1990-2015

Borg, W. R., \& Gall, M. D. (1983). Educational research, an introduction. London: Longman Inc.

Broome, S. A. (1989). Broome, S. A. (1989, April). The magic kids: A strategy to build selfesteem and change attitudes toward the handicapped. Paper presented at Annual convention of the council for exceptional children. In the 67th annual convention of the Council for Exceptional Children. San Francisco: Georgia learning Resources System.

Buller, P. F., \& McEvoy, G. M. (2012). Strategy, human resource management and performance: Sharpening line of sight. Human Reseurce Management Review, 22(1), 43-56. Retrieved from https://parsproje.com/tarjome/modiriyat/73.pdf

DuBois, D. L., \& Hirsch, B. J. (2000). Self-esteem in early adolescence. The Journal of Early Adolescence, 20(1), 5-11. https://doi.org/10.1177/0272431600020001001

Furqan. (2006). Penilaian hasil belajar untuk meningkatkan mutu pendidikan. Bandung: Universitas Pendidikan Indonesia.

Gecas, V. (1982). The self-concept. Annual Review of Sociology, 8(1982), 1-33. https://doi.org/10.1146/annurev.so.08.080182.000245

Guerra, N. G., Williams, K. R., \& Sadek, S. (2011). Understanding bullying and victimization during childhood and adolescence: A mixed methods study. Child Development, 82(1), 295310. https://doi.org/10.1111/j.1467-8624.2010.01556.x

Hattie, J. A. C., \& Donoghue, G. M. (2016). Learning strategies: A synthesis and conceptual model. Npj Science of Learning, 1(1), 16013. https://doi.org/10.1038/npjscilearn.2016.13

Huda, S. (2009). Kompeten sebagai basis pembangunan. Media Akademika, 26(3), 431-450.

Hurlock, E. B. (1959). Developmental psychology. New York: McGraw-Hill.

Indrawati. (2011). Perencanaan pembelajaran fisika: Model-model pembelajaran, implementasinya dalam pembelajaran fisika. Jember: Fakultas Keguruan dan ilmu Pendidikan Universitas jember.

Jiang, K., Lepak, D. P., Han, K., Hong, Y., Kim, A., \& Winkler, A. L. (2012). Clarifying the construct of human resource systems: Relating human resource management to employee performance. Human Reseurce Management Review, 22(2), 73-85. https://doi.org/https://doi.org /10.1016/j.hrmr.2011.11.005

Joyce, B., Weil, M., \& Calhoun, E. (2000). Models of teaching. New Jersey: Pearson Education, Inc. Konopka, A., \& Beers, W. Van. (2014). Composition work: A method for self-investigation. Journal of Constructivist Psychology, 27(3), 194-210. https://doi.org/https://doi.org/10.1080/10720537.2014. 904703

Lerner, R. M., \& Hultsch, D. F. (1983). Human development, a life span perspective. New York: McGraw-Hill.

Lyons, A. (2012). Self-esteem and learning disabilities Canadian family pharmacy speakes about disabilities association of Illinois. Retrieved March 29, 2017, from http://www.ldail.org/esteem.cfm

McClelland, D. (1953). The achievement motive. New York: Appleton-Century-Crofts.

Morrison, G. M., \& Cosden, M. A. (1997). Risk, resilience, and adjustment of individuals with learning disabilities. Learning Disability Quarterly, 20(1), 43-60. https://doi.org/10.2307/1511092

Mullai, E., Macaj, O., \& Kotherja, O. (2017). Selfie-mania influence on adolescent self-esteem. Interdisplinary Journal of Research and Development, IV(2), 95-100. Retrieved from https://goo.gl/W1ob1C

Murray, D. E. (2000). Changing technologies, changing literacy comunities. Language Learning \& Technology, 4(2), 43-58. Retrieved from http://llt.msu.edu/vol4num2/murray/ 
Mutekwe, E. (2012). The impact of technology on social change: A sociological perspective. Journal of Research in Peace, Gender and Development, 2(11), 226-238. Retrieved from https://goo.gl/W1ob1C

Papalia, D. E., Olds, S. W., \& Feldman, R. D. (1998). Human development. New York: McGrawHill.

Sadovnikova, T. (2016). Self-esteem and interpersonal relations in adolescence. Procedia - Social and Behavioral Sciences, 233, 440-444. https://doi.org/10.1016/J.SBSPRO.2016.10.181

Schwartz, S. E. O., Lowe, S. R., \& Rhodes, J. E. (2012). Mentoring relationships and adolescent self-esteem. The Prevention Researcher, 19(2), 17-20. Retrieved from http://www.ncbi.nlm.nih.gov/pubmed/24376310

Trianto. (2010). Mendesain model pembelajaran inovatif-progresif, konsep, landasan, dan implementasinya pada kurikulum tingkat satuan pendidikan. Jakarta: Kencana Prenada Media Group.

Tsang, S. K. M., Hui, E. K. P., \& Law, B. C. M. (2012). Positive identity as a positive youth development construct: A conceptual review. The Scientific World Journal, 2012, 1-8. https://doi.org/10.1100/2012/529691

Vihman, M. M. (2017). In search of a learning model. British Journal of Psychology, 108(1), 40-42. https://doi.org/10.1111/bjop.12229

Witzel, B. S., \& Mercer, C. D. (2003). Using rewards to teach students with disabilities. Remedial and Special Education, 24(2), 88-96. https://doi.org/10.1177/07419325030240020401

Yusuf, S. (2000). Psikologi perkembangan anak dan remaja. Bandung: Remaja Rosdakarya. 